\title{
Quality use of an unlicensed medicine and off label use of a medicine
}

\author{
Vasilka Nicha ${ }^{1}$, Maja Simonoska Crcarevska², Marija Glavas Dodov², \\ Renata Slaveska Raichki* \\ ${ }^{1}$ Public Institution in the Health Sector, for the needs of PHI University Clinics, Institution and Urgent Centre, \\ Majka Tereza 47, Skopje, Republic of Macedonia \\ ${ }^{2}$ Institute of pharmaceutical technology, Faculty of Pharmacy, University Ss Cyril and Methodius, \\ Majka Tereza 47, Skopje, Republic of Macedonia
}

Received: May 2014; Accepted: June 2014

\begin{abstract}
This paper gives an overview of the concept and process of quality use of unlicensed medicines and off label use of medicines, with special attention on the professional roles and responsibilities of prescribers and pharmacists. It also focuses on the policy requirements, sets of guidelines, recommendations, best practices, and other aspects addressed under this topic that represent the state of update knowledge. As a complex and specific issue, the use of an unlicensed medicine and off label prescribed medicine in different health care levels is of particular importance for the healthcare settings in the Republic of Macedonia since, the existing regulatory structure requires adoption and development of a comprehensive strategy relating to this topic in the near future with an aim of encouraging and supporting the development and maintenance of a sound health system with high standards of medication-use policies.
\end{abstract}

Key words: off label medicine, unlicensed medicine, quality use

\section{The legal foundation of the approval process of a medicinal product for human use}

Marketing authorizations (MA) for medicines and medical devices for human use are fundamentally granted by a competent regulatory authority in the form of an official approval (license) for a certain time period, based on a rigorous and comprehensive scientific, clinical, quality and cost- effective evaluation procedure. Globally speaking, several different regulatory approval processes can be distinguished, such as: federal (http://www. fda.gov) in the USA (regulatory scrutiny from Food and Drug Administration-FDA), centralized (Regulation (EC)

\footnotetext{
* tel.: +38923126032 ; fax: +38923123054
}

e-mail address: rera@ff.ukim.edu.mk
No726/2004), decentralized (Directive 2004/27/EC) and/ or mutual recognition procedures (Directive 2001/83/EC) in the member countries of the European Union (through the European Medicines Agency-EMA regulatory approval stringent pathways) and national approval processes for medicines and medical devices coordinated by the competent national authorities.

In our country, as a country with candidate status for EU membership and for reasons of approximation to the European legislation, an EU harmonized national MA system was installed by the latest Law on Medicinal Products and Medical Devices, promulgated in 2007 (LMPMD, 2007). Its implementation is more closely defined by a number of by-laws and rulebooks (https://lekovi.zdravstvo.mk). Some of the by-laws and rulebooks (Rulebook 1-2, 2008) clearly describe the steps of the entire procedure for MA of medicinal products or medical devices; regulate de- 
tailed requirements and submission of application dossier. In this context, according to Article 11 from LMPMD, medicinal product can be placed on the Macedonian market when:

- MA has been issued pursuant to the procedures prescribed by this Law,

- $\quad$ it is labeled and has patient information leaflet pursuant to the MA,

- import authorization was issued pursuant to this Law,

- quality control of medicinal products has been performed in line with the Law and

- $\quad$ it is used for preclinical or clinical trials providing that notification or authorization of clinical trial was issued.

Hence, a medicinal product can be placed on the Macedonian market only if it has a MA, issued by the Drug Agency as the national competent authority. Further, it has to be emphasized that the method of medicinal products prescribing must also be defined in the procedure for MA of medicinal product (Rulebook 3, 2008). To summarize, according to the Macedonian LMPMD, the MA medicines are generally divided into prescription only medicines (POM), over the counter medicines (OTC) and medicines for use only in healthcare institutions.

An application dossier for medicine MA is of substantial importance for the approval process. As an indispensable element of the approval process, an application dossier for medicine MA is a strict and comprehensive document with detailed requirements regarding the proof of quality, safety, efficacy and cost-effectiveness of medicine obtained from extensive pre-clinical tests and clinical trials (Directive 2001/83/EC). Application dossier also comprises all data concerning the medicine, including the name, pharmaceutical dosage form, indication fields, patient population, dose, risk information, etc., structured in the document known as "The Summary of Product Characteristics"- SmPC (Directive 2001/83/EC ). In this respect, $\mathrm{SmPC}$ for each medicine is a legal document approved as part of the medicine MA. Actually, it encompasses essential information for healthcare professionals regarding the use of the medicine, qualitative and quantitative information on the benefits and risks of the medicine for intended use, information for individualized care and basic pharmaceutical information. The development of the new emerging technologies contributes to the advance knowledge of the genomic factors so, when this knowledge is clinically relevant, it should also be presented in the SmPC. All information within SmPC is presented according to a predefined structure (Directive No 2001/83/EC, 2012; http:// eudrasmpc.eudra.org/). It is also worth mentioning that the enclosed patient information leaflet which is issued with dispensed medicine, and according to the law, must accurately reflect only the information presented in the SmPC (Directive No 2001/83/EC, 2012; Rulebook 4, 2009).
Medicines' approved uses are also indicated on their labels. An MA holder for a certain medicine is obligated to update the information submitted in support of the marketing authorization application, including information in relation to therapeutic indications, contraindications and adverse reactions. Nevertheless, it is worth to point out that $\mathrm{SmPC}$ is continuously updated throughout the life-cycle of the medicine, as new evidence and data emerge from postmarketing period and clinical experience.

\section{The existing definitions of off label use of a medicine and an unlicensed medicine use in the regulatory context and practice}

Prescribing practice of medicines for use outside the terms of their MA is known as off label (OL) use of a licensed medicines whereas, an unlicensed (UL) medicine use, in fact, is the use of a medicine that does not has MA. On the global regulatory scale, the term OL use of a medicine, by wider definition, refers to the use which is outside the information in SmPC or more precisely, it denotes a use which is not specified on the product labeling and instructions for use. It is apparent, as a consequence, that this use of a medicine has not been evaluated nor approved by the regulatory authorities and therefore has less supporting evidence stipulated by MA process. As a result, it is not simple to define and regulate this issue. Moreover, there is a noticeable inconsistency in theliterature data of how the terms "off-label", "unlabeled", "unproved", "unlicensed" or unregistered" prescribing and use of medicines are defined and mentioned in different types of studies and purposes (Gazarian, 2007). From the pharmaceutical point of view, for example, in some studies extemporaneously prepared pharmaceutical formulations under the direct supervision of a pharmacist are considered as an unlicensed formulation due to additional pharmaceutical modification of the marketing approved pharmaceutical product (e.g. pharmacy compounded formulations, such as preparation of a rectal enema from licensed parenteral dosage forms) whereas others include them in the category of OL use of medicines (Conroy et al., 2000;). Hence, UL medicines may also include a medicine whose licensed formulation is modified; those that are imported in the country prior a license (MA) has been granted; or those that are chemical entities used for therapeutic purposes. As the legal status of OL use of medicines and use of UL medicines is not the same it is important to clearly distinguish the meaning of these terms and definitions. Other related terms describing OL use of medicines are as follows: "out-of-label use," and "usage outside of labeling". According to FDA, the sometimes used term "unapproved use" of medicines should be avoided because it implies that FDA regulates prescribing and dispensing activities (ASHP, 1992). In our country, according to Article 11 from LMPMD: “ ...medicinal product, without $M A$, can be available on the ba- 
Table 1. The terms used to describe the OL use of MA medicines and UL medicine use by EMA, FDA, WHO, and medication use policy in UK

\begin{tabular}{|c|c|c|c|c|}
\hline & $\begin{array}{l}\text { Extemporaneously } \\
\text { Prepared Medicines }\end{array}$ & $\begin{array}{l}\text { "Off-label" and "off- } \\
\text { license" use of med- } \\
\text { icine }\end{array}$ & Unlicensed medicines & Specials \\
\hline UK & $\begin{array}{l}\text {-an unlicensed medi- } \\
\text { cine made in a phar- } \\
\text { macy under the direct } \\
\text { supervision of a phar- } \\
\text { macist }\end{array}$ & $\begin{array}{l}\text {-UK licensed medi- } \\
\text { cine used outside of } \\
\text { its license }\end{array}$ & $\begin{array}{l}\text { do not have: } \\
\text { - a UK MA number } \\
\text { issued by the regula- } \\
\text { tory authority, } \\
\text {-a European MA is- } \\
\text { sued by the EMA for } \\
\text { use in the UK }\end{array}$ & $\begin{array}{l}\text {-an unlicensed med- } \\
\text { icine, specially pre- } \\
\text { pared by the hold- } \\
\text { er of a Manufacturers } \\
\text { Special License, to } \\
\text { satisfy an individual } \\
\text { patient's special need }\end{array}$ \\
\hline EMA & \multicolumn{4}{|c|}{$\begin{array}{l}\text { "Off-label" use of medicine } \\
\text { - intentionally used outside the terms of MA }\end{array}$} \\
\hline WHO & \multicolumn{4}{|c|}{$\begin{array}{l}\text { "Off-label" and "off-license" use of medicine } \\
\text { - use of medicine outside the specifications described in the license (e.g. in terms of formula- } \\
\text { tion, indications, contraindications or age) }\end{array}$} \\
\hline FDA & \multicolumn{4}{|c|}{$\begin{array}{l}\text { "Unlabeled uses" of medicines } \\
\text {-uses that are not included in the indications or dosage regimens listed in the FDA approved } \\
\text { product labeling (not approved labeling reflected in FDA), in: } \\
\text { (1) doses,(2) patient population, (3) indications, (4) routes of administration }\end{array}$} \\
\hline
\end{tabular}

sis of compassionate use e.g. for compassionate reasons to a group of patients with a chronically or seriously debilitating disease or whose disease is considered to be life threatening and who cannot be treated satisfactorily by other authorized medicinal product. The medicinal product stipulated in paragraph 2 of this article must either be subject of a procedure for marketing authorization or must be undergoing a clinical trial". Despite the fact that, an unlicensed medicine uses are precisely described and regulated, off label medicinal product are not mentioned and defined in our policy (LMPD, 2007).

To summarize, Table 1 presents the terms explaining the meaning of UL medicine use and OL use of medicines described by the regulatory body and medication use policy in UK as an example of EU country.

The most comprehensive definitions of OL medicine uses in pediatric population are presented in details in Table 2, as an example for highlighting the distinction of several OL categories of medicinal uses (Ufer et al., 2003; Ufer et al., 2004; Kimland et al., 2007),

Nevertheless, both OL prescribing and use of MA medicines should be distinguished from improper prescribing, illegal use and medication errors. In line with this, the practice is experiencing greater challenges since the categories of UL and OL use of licensed medicine are particularly vulnerable to misunderstanding by professionals and public. These raise many questions and sometimes cause confusion and concerns that can serve as indication point for more consideration and attention by all interested parties.
Table 2. OL categories use of medicines in pediatric population

\begin{tabular}{ll} 
Off-label category & Description \\
\hline Age & $\begin{array}{l}\text { Drug not recommended in the } \\
\text { SmPC below a certain age }\end{array}$ \\
Weight & $\begin{array}{l}\text { Drug not recommended in the } \\
\text { SmPC for children below a cer- } \\
\text { tain weight }\end{array}$
\end{tabular}

Absence of pediat- Pediatric use not mentioned at all ric information in the SmPC

Lack of pediatric Statement about the lack of evclinical data idence of efficacy and safety in pediatric patients in the SmPC

Contraindication Statement in the SmPC that the drug is contraindicated in children

Indication Drug prescribed for indications outside of those listed in the $\mathrm{SmPC}$

Route of adminis- Drug administered by a route not tration described in the SmPC 


\section{Statistical data about OL use of licensed medicines and UL medicine use}

The considerable evidences of OL and an UL medicine prescribing practices and the extent of their application in different patient care levels strongly confirm this widespread practice supported by the overall experiences gained from many studies and surveys (Conroy et al., 2000; Shah et al., 2007; EMA/794083/2009, 2011). In fact, an UL and OL use of licensed medicines is not illegal and the outcomes should not be underestimated particularly when all other options of licensed medicines are unavailable, exhausted, not tolerated, ineffective or unsuitable for patient's healthcare needs. For these underlying reasons, in some instances an UL and OL medicine application may be the only choice or the best available access to therapy for vulnerable population such as obstetric (Colvin et al., 2013) pediatric ('tJong et al., 2001; Bavdekar and Gogtay, 2005; Bellis, et al., 2013; Silva et al., 2014), oncologic (Pool and Dooley, 2004; Soares, 2005), geriatric (Dautzenberg et al., 2009) and psychiatric (Chouinard, 2006; Hall et al., 2001) patients as well as patient on palliative care or with terminal disease condition (Pavis and Wilcock, 2001; Culshaw et al., 2013;). Indeed, OL prescribing is also common for so-called therapeutic orphan populations and/or rare diseases treatments and special condition (Hampton, 2007; Conroy et al. 2000; Shah et al., 2007). On the other hand, some older, generic medicinal products have been routinely prescribed as OL for many years (Lindell-Osuagwu et al., 2009; Rocchi et al., 2010). Global statistical data confirm that in certain patient groups, OL use of medicines has been proven to be prevalent and in some cases used even as a common therapeutic strategy, whereas in others it may be the only treatment option and/or standard of patient health care. For example, the most extensive statistical data originating from pediatric population studies confirm that the overall rates of OL and unlicensed medicines prescriptions ranged from $45-60 \%$ up to $90 \%$ at different care levels (EMA/794083/2009). Furthermore, based on recent scientific evidence, the OL medicine use may allow the patients to access innovative and new medicines or in the case of approved medicines for example, to implement new indications, dose or route of administration (Lindell-Osuagwu et al. 2009; Rocchi et al., 2010; Kimland and Odlind, 2012). Moreover, many new discoveries and experiences from OL use of medicines and an UL medicine in continuum have not surprisingly contribute to redesign the accepted and "best practice" standards of patient care. These findings emerge much more rapidly than the regulatory authority approves new uses for the marketing approved medicines. It is estimated that around 1,000 specific requests for OL drug use are made to NHS commissioners in England every year (www.nice.org, 2014). In one study, 57\% of the medicines therapy innovations were discovered by clinicians, without involvement of pharmaceutical companies or researches (De Monaco et al, 2006). Thus, the im- portant role of clinicians in the discovery of OL medicines therapies and identification of positive or negative unexpected effects is strongly confirmed. However, a survey of 150 million OL prescriptions in the United States found that $73 \%$ had little or no scientific support (Gazarian et al., 2006). By all aspects, the potential of OL and an UL medicines use to expose a patient to harmful consequences is more pronounced when this use is less supported and justified by solid scientific and medical evidence. Hence, patients might be at risk of receiving harmful or ineffective treatments. The percentage of an UL and/or OL prescriptions involved in an adverse drug reaction ranged between 23 and $60 \%$ in pediatric population (Cuzzolin et al, 2006).

In view of the fact that in many areas of medical practice, the patient care could not proceed without OL prescribing, there is no doubt that this practice and its valuable role is an integral part of contemporary health care. Therefore, regulatory authorities and professional bodies are expected to ensure clearer understanding and enforce actions and standards by applying in practice the guiding principles designed to address the quality use of an unlicensed medicine and OL use of a medicine.

Since, many clinical and ethical concerns and challenges refer to the extent, scope and possible effects and consequences of such prescribing and use of medicines, some guidelines for prescribers, clinicians, and pharmacists with regard to the use of an UL medicines and OL use of a licensed medicines in every level of health care have been developed and adopted and others will follow in the near future, with the aim of ensuring and supporting the safe use.

Recognizing this issue as an issue of grave concern, in our country there is a need of initiating a framework as a technical support package for dealing with this specific topic.

\section{Basic policy framework for OL use of a licensed medicine and an UL medicine use}

As mentioned above, there are diverse, complex and justified reasons for OL use of medicines and use of UL medicines which are not illegal if their prescription, compounding and use are strictly regulated and evaluated for appropriateness and safe use (ASHP, 2008; http://www. gmc- uk.org/). Over the years, many potential implications of OL use of medicines have been arising for example, patient's insurance costs, regulatory and legislative implication (e.g. risk:benefit ratio; possible redefinition of the evidence-based standard of medication practice, liability for not applying well-described OL use of medicine), clinical implication (safety and efficacy of OL use), ethical issues and economic trends of pharmaceutical companies (Ventola, 2009 ). By all aspects, statistical data about the extent, possible effects and consequences of the use of the medicines UL and OL strongly confirm the need for national policy framework that will regulate this issue in order to 
ensure quality use. This implicates a need to establish: national policies governing OL prescribing and compounding, ethical standards and policy reforms to promote patient and public interests in evidence-based OL prescribing (NHS/Wirral, 2010). A number of initiatives emerge with the aim to stimulate evidence-based OL medicine use (Dresser and Frader, 2009; CATAG, 2013). First of all, regulatory authorities within health system should basically do the following:

- determine the need for UL and OL medicines,

- adopt national policies that will regulate the OL prescribing,

- regulate certain OL uses,

- promote ethical standards that will regulate the OL prescribing,

- stimulate policy reforms to promote patient and public interests in evidence-based OL prescribing.

Moreover, it is necessary to propose and adopt policy measures that could decrease risky and ineffective OL prescribing. Systematic monitoring of patient responses to OL uses with regular information collection about OL uses and making them publicly available are other aspects that have to be fulfilled. Monitoring the OL use and record keeping about different patient population by indication and active collecting of safety data should be conducted on regular basis. For example, to continuously monitor OL use of a medicinal product, patient's medical records, general practice data bases and hospital prescribing data bases should be created and used (ASHP, 2008). Professional roles and shared responsibilities (clinical and legal liability) of prescribers and pharmacists should also be clearly defined in order to follow the process of OL medicine use including ethical standards governing OL prescribing. Some countries developed design requests from secondary or tertiary care (e.g. in the form of a flow chart) supported by steps, roles and responsibilities of prescribers when initiation starts in secondary and tertiary health care (NHS/Wirral, 2010).

\section{Approaches of assessing appropriateness in OL prescribing and ethical justification}

Like any other complex process in health care, medicine prescription process should be based on empirical knowledge, experience, law regulations and rational steps. The main objective of each medicine prescribing is to have a clear therapeutic goal supported by evidence regarding the safety and effectiveness. Actually, health professionals with specialized clinical and therapeutics expertise in relevant area, when making prescribing judgment and taking decisions, should practice evidence based evaluation approach. Medicine prescribing justified by high-quality evidence in one step includes evaluation process based on the following sources: a new drug monograph, addenda to original monographs, therapeutic class reviews, and expedited reviews (ASHP, 2008). Regarding scientific and clinical evidence that can justify and support any medical intervention including prescribing, the proposed hierarchy of evidence is the following: 1) Large randomized controlled trials-RTC; 2) Smaller RCT; 3) Cohort studies; 4) Poorly controlled or uncontrolled studies; 5) Case reports and 6) Expert's opinion (Harbour and Miller, 2001). There is no doubt that all objectives of responsible prescribing are as relevant for OL prescribing as they are for label prescribing. However, since OL interventions have different objectives mentioned above, it prompts different ethical implications in specific patient populations. For example, in some circumstances, OL prescribing can be ethically justified on the basis of evidence that would be considered inadequate in other contexts (Dresser and Frader, 2009). At the same time, taking into account that regulatory authorities (c.a. FDA) cannot approve or disapprove physician and clinicians prescribing practices of MA drugs, OL prescribing is an area of practice that is not directly regulated by regulatory authorities. The appropriate approach of OL prescribing can be challenging for any prescriber in fact, this is a major issue of concern.

The common strategy of responsible OL prescribing requires several basic elements (Dresser and Frader, 2009):

- Explicit guidelines to help prescribers assess the appropriateness of OL prescribing,

- Justifying OL prescribing by high-quality evidence,

- Providing additional information and research data whenever adequate evidence is lacking

- Informing about the uncertainties and potential costs associated with OL prescribing

According to the main principle developed for Australian Hospitals the following four categories of OL use are distinguished, which can be supported by different levels of evidence and clinical circumstances (CATAG, 2013):

- routine OL use of medicine,

- exceptional/individual OL use of medicine,

- conditional OL use of medicine, with evidence development,

- research or investigational OL use of medicine.

Proposed routine of OL clinical use of a medicine refers to the use which is based on high quality evidence for safe, efficacious and cost-effective use. Exceptional/individual OL medicine use denotes patient treatment favorable in individual clinical circumstances where distinct prespecified criteria are met (e.g. serious or rare condition) or where alternative treatments are not available, or have been exhausted and/or failed. This OL category use is supported by low or very low quality evidence but the overall benefit: harm ratio may be advantageous in this individual use. The third category, defined as conditional OL use with evi- 
dence development, covers use support with low to moderate quality evidence in certain types of patients or group of patients according to an agreed protocol. Therefore, it is very important to observe the effectiveness and safety outcomes with subsequent record keeping, as it can contribute to systematic development of evidence base about that drug for the benefit of other patients. For this use the relevant group of patients is also defined by pre-specified criteria (e.g. disease type and severity, age, tried and failed standard treatment). The fourth OL category use in fact, is classified as investigational or experimental use because it is recommended when there is low or very low quality of evidence, with uncertain benefits and harms that are unknown or which may be significant. However, because of the potential of clinical benefit for the patient, a research protocol should be used and reviewed and approved by a Ethics Committee (CATAG, 2013)

Use is not recommended, when a proposed OL use does not fit into any of the above the aforementioned four categories.

It is obvious that determining the appropriateness of OL prescribing has been associated with difficulties and it is not easy task to accomplish. While, making efforts to successfully manage the OL prescribing of a medicine, many medical organizations and societies have been working to issue guidelines; propose the consensus recommendations to help physicians and clinicians assess appropriateness and decision making in OL prescribing. For example, American Academy of Pediatrics Committee on Drugs (AAP, 2014) endorses OL prescribing based on sound scientific evidence, expert medical judgment, or published literature and done in line with the best interest of the patient.

In detail, according to ASHP the following principles should guide the OL prescribing and use of medicines (ASHP, 2008):

1. Whenever possible, OL prescribing should be based on published evidence,

2. Patient safety should always be priority,

3. The Pharmacy and Therapeutic (P\&T) committee should be involved to establish protocols guiding the most frequent OL use,

4. The P\&T committee should guide its decisions based on the scientific evidence,

5. The P\&T committee should monitor of OL uses,

6. The ultimate responsibility for the safety and efficacy of OL use resides with the prescriber.

1. Prescribers should be familiar with the evidence before considering OL use,

2. Prescribers should be aware of established protocols for use,

3. When necessary, the prescriber should consult with a knowledgeable pharmacist,

7. Proper assessment of evidence for OL use should involve as comprehensive and balanced review as possible,
8. It is strongly recommendable to avoid selective use of studies to support a decision.

According to MHRA the prescribers have to consider tree aspects: appropriateness of OL and UL medicine used, patient information and report suspected adverse reaction. Thus, the advices for prescriber are to: "Prescribe UL medicine or OL medicine for use", when:

- Available licensed medicine alternative does not meet the patient's needs,

- Sufficient evidence base and/or clinical experience can support safe and effective use:

- both responsibility for prescribing and for supervising the patient's care, including monitoring and follow-up can be taken,

- records of the medicine prescribed are kept,

- $\quad$ records are kept for all discussed issues with the patient.

Regarding the "communication to patient", the best practice requires:

- $\quad$ sufficient information about the proposed treatment, including known serious or common ADR's to make available to patients, so as to allow them to make an informed decision,

- $\quad$ to give as much information as patients or carers require or which they may see as relevant,

- to explain the reasons for prescribing an $\mathrm{OL}$ medicine or prescribing an unlicensed medicine where there is little evidence to support its use, or where the use of a medicine is innovative.

Prescribers are advised to discuss with patients about potential benefits and harms of OL applications (Eichler, H., et al, 2009).

Report on suspected adverse reactions is the third aspect of OL and UL use that should be fulfilled by healthcare professionals. They have a responsibility to help monitor the safety of medicines in clinical use through submission of suspected adverse drug reactions to the Institutions (MHRA 2009).

The ethical justification for OL prescribing by definition, aims to provide the best available therapy for a particular patient and/or patient populations. At least three ethical considerations relevant to OL prescribing can be distinguished (Dresser R., Frader J., 2009):

- evaluation process of the existing evidence for OL prescribing,

- gathering information and conducting additional research when there is inadequate evidence about an OL use and

- disclosing to patients the reasons about off-label interventions. 
To summarize, prior to making a decision, it is of paramount importance to consider the overall benefits and risks of OL medicine use, to inform and communicate to the patient with record keeping and to report on ADR's. In line with this, prescribers have been expected to use their "professional judgments, knowledge and experience" to determine the appropriateness of such prescribing in individual patients or patient population and ultimately to apply evidence-based principles in making clinical decisions about OL or an UL medicines use. However, in practice, it is obvious that clinicians are often faced with limited available data or no data at all and/or no explicit guidance in implementing such judgments and for that reason very often only a small proportion of OL prescribing may be justified by scientific evidence.

\section{A model strategy on OL use according to NHS in UK}

The National Health System (NHS) of UK offers a more practical and explicit approach with guidelines and flow charts that support the decision making process of prescribers regarding the OL medicine prescribing and use. In this strategy, all the aforementioned principles are included as follows:

- Determining the need for unlicensed and OL medicines,

- Guidelines regarding alternatives of tablets/ capsules (flow chart),

- Defining roles and responsibilities (clinical responsibility and legal liability) of prescribers of unlicensed and OL medicines,

- Defining steps (flow chart) and roles and responsibilities of prescribers when initiation starts in secondary and tertiary care,

- Requests from secondary or tertiary care (flow chart),

- Patients with professional carers - advice for prescribers \& carers,

- Roles and responsibilities of pharmacists,

- Guidelines for pharmacists \& dispensers when sourcing unlicensed and OL medicines,

- Reporting adverse drug reactions (ADR's),

- Records keeping.

\section{Roles and responsibilities of pharmacists regarding OL product}

The main professional role and responsibility of a pharmacist is to ensure that patients receive a medicine and therapy that is safe, effective, and appropriate for their medical condition and the circumstances, with minimal risk and at lower cost. ASHP believes that pharmacists in organized healthcare settings bear a significant responsibility for ensuring optimal outcomes from all drug thera- py (JCCP, 2014). The so called standard "fit for purpose" should be achieved by quality and clinically appropriate medication for the individual patient and all this is equally important for "UL/OL medicines". Since UL/OL is prescribed by prescriber and supplied by a pharmacist only when there is no available licensed medicine which fully meets the patient's clinical needs, the pharmacist first of all, should offer guidance to alternatives of pharmaceutical dosage forms as tablets/capsules presented in the flow chart to help physicians and clinicians in decision making for OL prescription. A pharmacist can supply an unlicensed product only by exception and with the full knowledge of the prescriber. Pharmacists and dispensers when sourcing unlicensed and OL medicines need to follow certain guidelines in order to understand their legal responsibilities when supplying OL product and minimize the legal risk of patients and pharmacist. When compounding OL or UL medicines, pharmaceutical standard of practice should be applied where possible, or relevant international standards such as those developed by the World Health Organization and the Pharmaceutical Inspection Convention and Pharmaceutical Inspection Co-operation (PIC/S) as well as chapters and monographs of the European Pharmacopoeia containing general and specific requirements applicable to medicinal products prepared in pharmacies, in particular about the standards and methods for the control of the chemical, pharmaceutical and microbiological quality of active substances and excipients, about dosage forms and containers. However, it is also important to carry out risk assessment in order to make a distinction between so called "low risk" preparations (where PIC/S GPP Guide is recommended as reference) and "high risk" preparations (where GMP Guide is recommended as reference). Pharmacist should also confirm that the OL product meet the relevant standard of safety and quality regarding the certificate of analysis or the certificate of conformity. One of the duties of the pharmacist is to ensure evidence to support the labeled shelf life of the OL product. Moreover, pharmacist is also responsible to ensure that the OL product is pharmaceutically appropriate and suitable for the patient (e.g. to confirm the strength, choice of formulation and excipient details on the certificate, and where applicable, on the label). Reporting ADR's reactions of OL product is the key role of the pharmacist, as well. Record keeping for all activities of the pharmacists involved in OL medicines is their inevitable obligation. Other recognized duties of pharmacists are to disseminate medicine information in areas where decisions are being made about drug therapy and to communicate with other health care professionals about recognition, documentation, and prevention of medication errors and educate patients and care givers. American Society of Hospital Pharmacists statement on the use of medications for unlabeled uses describes Pharmacist's Role as the following (ASHP, 1992):

To fulfill the roles of patient advocate and drug information specialist, 
- To develop policies and procedures for evaluating prescriptions and dispensing drugs for UL uses in their own work settings. Such policies and procedures might address the documentation of scientific support, adherence to accepted medical practice standards, or a description of medical necessity,

- Develop proactive approaches to promote informed decision making by third-party payers of health-care services.

\section{Promotion of OL medicines}

OL promotion is very different from OL use. On one hand, it is legal for physicians and clinicians to use OL medicines; on the other hand, for pharmaceutical companies it is usually not legal to promote their product for off label use and sale. Thus, bearing in mind that the promotion practice of OL use of medicines by pharmaceutical companies is still prohibited, for example in UK, MA holders are not allowed to promote 'OL' use while, FDA prohibits the promotion of drugs and devices for OL uses by companies (Ventola, 2009). However, FDA permits the following sources for Off-label information such as compendia and drug information references, Continuing medical education, Journal articles, medical and graduate education, medical liaisons, sales representatives and web sites. In our policy, as described in the "Guidelines on the manner of drugs and medical aids advertising", Article4: The advertising for drug should be performed in compliance with the approved patient information leaflet and the summary of medical product characteristics. However, nothing is mentioned about the prohibition of OL promotion of medicines. Despite prohibited OL promotion by pharmaceutical industry companies it is obvious that independent opinion and practice of leading and influential academic clinicians and physicians via scientific articles, congress presentation and other professional activities for information dissemination can launch OL uses, stimulate OL prescribing and provide key references for valuable $\mathrm{OL}$ uses. They can also be identified as crucial factors in the "promotion" of OL medicinal uses.

\section{Conclusion}

The main objectives of any contemporary health system are to establish health care policies, health technologies and medicines use policies. Beside the use of licensed medicines, there is a widespread practice of prescribing and use of "unlicensed" medicines and "off label" use of licensed medicines which are not illegal if their prescription, compounding and use are strictly regulated and evaluated for appropriateness at every heath care level. Health care practitioners (prescribers, clinicians, pharmacists) have important roles and responsibilities in the control and validation of this process. In general, they are urged to apply evidence-based principles in decision making process for OL or UL medicines use; to consider the overall benefits and risks of OL medicine use and to report on ADR's.

\section{References}

AAP, 2014. American Academy of Pediatrics. Off label use of drugs in children. Pediatrics. 133, 563-567.

ASHP, 1992. American Society of Hospital Pharmacists (ASHP) Statement on the use of medications for unlabeled uses. Am. J. Hosp Pharm. 49, 2006-2008.

ASHP, 2008. American Society of Health System Pharmacists (ASHP) guidelines on the pharmacy and therapeutics committee and the formulary system. Am. J. Health Syst. Pharm. 65,1272-83. Bavdekar, S.B., Gogtay,N.J., 2005. Unlicensed and Off label use in children. J.Postgrad. Med 51, 249-252.

Bellis, J. R., Kirkham, J.J., Thiesen, S., Conroy, E.J, Bracken, L.E., Mannix,H.L., Bird, K.A., Duncan, J.C., Peak, M., Turner, M.A., Smyth, R.L., Nunn, A.J., Pirmohamed, M., 2013. Adverse drug reactions and off-label and unlicensed medicines in children: a nested case-control study of inpatients in a pediatric hospital. BMC Medicine, 13, 11, 238 (http://www.biomecentral.com/1741-7015/11/238)

CATAG, The Council of Australian therapeutic Advisory Group (CATAG), 2013. Rethinking medicines decision making in Australian Hospitals: Guiding Principles for the quality use of off- label medicines.

Chouinard, G., 2006. The Search for New Off-Label Indications for Antidepressant, Antianxiety, Antipsychotic and Anticonvulsant Drugs. J. Psychiatry. Neurosci. 31(3), 168 -176 .

Colvin, L., Gill, W.A., Slack-Smith, L., Stanley, J. F., Bower, C., 2013. Off-Label Use of Ondansetron in Pregnancy in Western Australia. BioMed Res.Int. Article ID 909860 (http://dx.doi. org/10.1155/2013/909860). (Assessed March 2014).

Conroy, S., Choonara, I., Impicciatore, P., Mohn, A., Arnell, H., Rane, A., Knoeppel,C., Seyberth,H., Pandolfini, C., Raffaelli, M.P., Rocchi,F., Bonati,M., Jong, G., De Hoog, M., Van den Anker, J., 2000. Survey of unlicensed and off label drug use in paediatric wards in European countries. BMJ. 320 (7227), 79-82.

Culshaw, J., Kendall, D., Wilcock, A. 2013. Off-label prescribing in palliative care: A survey of independent prescribers. Palliat. Med. 27(4), 314-319.

Cuzzolin, L., Atzei, A., Fanos V. 2006. Off-label prescribing for newborns in different settings: a review of the literature and a consideration about drug safety. Expert opinion on drug safety. 5(5),703-718 ( doi. 10.1517/14740338.5.5.703).

Eichler, H., Abadie, E., Raine, J.M., Salmonson, T. 2009. Safe Drugs and the Cost of Good Intentions. NEJM 360(14) 1378-1380. [PubMed: 19339718]

Dautzenberg, P.L., van der Zande, J.A, Conemans, J. M., Rikkert, M.G. 2009. Off-label drug use on a Dutch geriatric ward. Int. J. Geriatr. Psychiatry. 24(10), 1173-1174.

De Monaco, HJ., Ali A., Von Hippel E., 2006. The Major Role of Clinicians in the Discovery of Off-Label Drug. Pharmacotherapy. 26(3), 323-332. 
Directive 2001/83/EC of the European Parliament and of the Council on the Community code relating on medicinal products for human use. Consolidated version 16/11/2012 http://ec.europa.eu/ (Accessed August 2014).

Directive 2004/27/EC of the European Parliament and of the Council, http://eur-lex.europa.eu (Accessed August 2014).

Dresser, R., Frader J., 2009. Off-Label Prescribing: A Call for Heightened Professional and Government Oversight. J Law Med Ethics. 2009 ; 37(3): 476-396

EMA/794083/2009, European Medicine Agency (EMA), Report on the survey of all paediatric uses of medicinal products in Europe at http://ema.europa.eu/docs/en_GBdosument library/Report/2011/01WC500101006.pdf. ${ }^{-}$(Accessed March 2014).

Gazarian, M., Kelly, M., McPhee, J. R., Graudins, L.V., Ward, R.L., Campbell, J. T. 2006. Off- Label Use of Medicines: Consensus Recommendations for Evaluating Appropriateness. Med. J. of Australia 185(10), 544-548.

Gazarian, M. 2007. Off-label use of medicines in the paediatric population: recommendations for assessing appropriateness. archives. who.int/eml/expcom/children/Ithems/ WHOofflabel.pdf (Accessed August 2013).

Guidelines on the manner of drugs and medical aids advertising. Official Gazette of the Republic of Macedonia, No. 66/08.

Hall, D.S, Fuller, A., Banham G.S. 2001. An analysis of offlicence prescribing in psychiatric medicine. Pharm J. 267, 890-891

Hampton, T. 2007. Experts weigh in on promotion, prescription of off-label drugs. JAMA. 297(7), 683-684.

Harbour, R., Miller, J. A. 2001.New System for Grading Recommendations in Evidence Based Guidelines," BMJ 323, 7308, 334-336. http://lekovi.zdravstvo.mk. (Accessed August 2014) 4

http://www.gmc-uk.org/Prescribing_Guidance_2013_50955425. pdf. Prescribing Medicines and managing medicines and devices. (Accessed September 2014). http://www.mhra.gov. uk/home/groups/pl-p/documents/publication/con043810.pdf (Accessed September 2014).

http://www.nice.org.uk/about/what-we-do/our-programmes/ nice-advice/evidence-summaries- unlicensed-or-off-labelmedicines. (Accessed August 2014). http://www.fda.gov/ Drugs/DevelomentApprovalProcess/ucm090410.htm. (Accessed March 2014). JCCP, 2014: Pharmacist's Patient care Process,

http://www.ashp.org/DocLibrary/BestPractices/ JCPPCareProcess2014.aspx (Accessed May 2014).'t Jong, G.W., Vulto, A.G., de Hoog, M., Schimmel, K.J.M., Tibboel, D., van den Anker, J.N., 2001. A survey of the use of offlabel and unlicensed drugs in a Dutch Children's Hospital. Pediatrics 108(5), 1089-1093.

Kimland, E., Odlind V., 2012. Off-label Drug Use in Pediatric Patients. Clin. Pharmacol. \&Ther. 91,786-801.

Kimland, E., Bergman, U., Lindemalm, S., Böttiger, Y., 2007. Drug related problems and off-label drug treatment in children seen at a Drug Information Centre. Eur. J. Pediatr. 166,527-32.

Lindell-Osuagwu, L., Korhonen, MJ., Saano, S., HelinTanninen, M., Naaranlahti T., Kokki H., 2009. Off-label and unlicensed drug prescribing in three paediatric wards in Finland and review of the international literature. Journal of Clinical Pharmacy and Therapeutics. 34, 277-287.

LMPD, 2007. Law on Medicinal Products and Medical Devices. Official Gazette of the Republic of Macedonia, No. 106/2007.

MHRA, 2009. Off label and unlicensed use of medicines: prescribers' responsibilities. Drug Safety, Update, 2(9) 6-7.

NHS/Wirral, 2010. Medicine Management. Guidance on Unlicensed and "Off label" medicines. http://mm.wirral. nhs.uk/document_uploads/guidelines/WirralSpecialsMar11. pdf

Pavis, H., Wilcock, A. 2001. Prescribing of drug for use outside their license in palliative care: survey of specialist in the United Kingdom. BMJ. 323(3), 314-319.

Poole, S.G., Dooley, M.J. 2004. Off-label prescribing in oncology. Support Care Cancer. 12(5), 302-305.

Regulation (EC) No 726/2004 of the European Parliament and of the Council, http://eur- lex.europa.eu (Accessed August 2014).

Rocchi, F. Paolucci, P., Ceci, A., Rossi, P. 2010. The European pediatric legislation: Benefits and perspectives. Italian Journal of pediatrics, 36-56.

Rulebook 1. Rulebook for renewal of the marketing authorization for medicinal products. Official Gazette of the Republic of Macedonia, No. 65/08.

Rulebook 2. Rulebook on issuance of marketing authorization for medicinal products. Official Gazette of the Republic of Macedonia, No. 29/08.

Rulebook 3. Rulebook on the manner of prescribing and dispensing medicinal products on a prescription. Official Gazette of the Republic of Macedonia, No. 153/08.

Rulebook 4. Rulebook on the structure and the contents of the package leaflet for medicinal product. Official Gazette of the Republic of Macedonia, No. 29/09.

Shah, S.S., Hall, M., Goodman, D.M., Feuer, P., Sharma, V., Fargason, C. Jr., Hyman, D., Jenkins, K., White, M.L., Levy, F.H., Levin, J.E., Bertoch, D., Slonim, A.D. 2007. Off-label Drug Use in Hospitalized Children. Arch. Pediatr. Adolesc. Med. 161(3), 282-290.

Silva, D., Ansotegui, I., Morais-Almeida,M. 2014. Off label prescribing for allergic diseases in children. WAOJournal. 7(1)4. Published online Feb 14, 2014. doi: 10.1186/19394551-7-4. (Assessed June 2014).

Soares, M., 2005: Off-label indications for oncology drug use and drug compendia: history and current status. J Oncol Pract.1(3), 102-105.

Ufer, M., Kimland, E., Bergman, U. 2004. Adverse drug reactions and off-label prescribing for paediatric outpatients: a one-year survey of spontaneous reports in Sweden. Pharmacoepidemiol Drug Saf.13,147-152.

Ufer, M., Rane, A., Karlsson, A., Kimland, E., Bergman, U. 2003. Widespread off label prescribing of topical but not systemic drugs for 350,000 paediatric outpatients in Stockholm. Eur. J. Clin. Pharmacol. 58,779-783.

Ventola, CL., 2009. Off-label Drug Information: Regulation, Distribution, Evaluation, and Related Controversies. P\&T. Vol.34 No. 8, 428-449. 


\title{
Резиме
}

\section{Квалитетна примена на нерегистрирани лекови и неодобрена употреба на регистрирани лекови}

\author{
Василка Ничаㄹ, Маја Симоноска Црцаревска², Марија Главаш Додов², \\ Рената Славеска Раички ${ }^{2 *}$

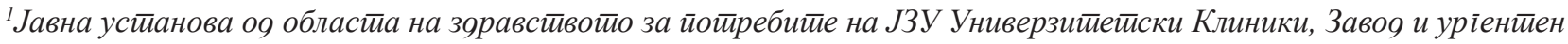 \\ ценитар, Мајка Тереза 47, 1000 Скойје, Рейублика Макеоонија

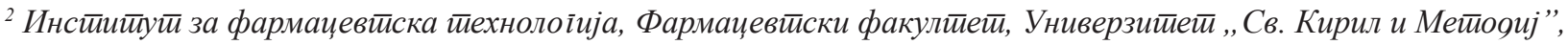 \\ Мајка Тереза 47, 1000 Скойје, Рейублика Макеоонија
}

Клучни зборови: нерегистрирани лекови, неодобрена примена на регистрирани лекови, квалитетна примена

Трудот дава преглед на концептот и процесот за квалитетна примена на нелиценцирани лекови и неодобрена примена на лиценцирани лекови со посебен акцент на професионалните улоги и одговорности на пропишувачите на лекови и фармацевтите. Исто така, во фокусот на интерес се ставени регулаторните барања, водичите, препораките, најдобрите практики и сите аспекти на најнови сознанија од оваа област. Примената на нелиценцираните лекови и пропишувањето на лекови за неодобрени индикации во различни нивои на здравствената грижа, како комплексно и специфично прашање, е од посебен интерес за здравствените капацитети во Република Македонија, од причина што постоечката регулатива во блиска иднина има потреба од усвојување и развој на опсежна стратегија поврзана со оваа област со цел да се поттикне и поддржи развој и унапредување на здравствен систем со високи стандарди. 